\title{
The Effect of Combined Aquatic Exercise on Body Composition, Muscular Function, Static Balance and Visual Analogue Scale in Female Elderly with Knee Osteoarthritis
}

\author{
Bee-Oh Lim', Sung-Sun Kang ${ }^{2}$, Ji-Hoon Cho ${ }^{3 *}$, Jung-Wha Moon ${ }^{4 *}$ \\ 'Chungang University, Seoul, Korea \\ ${ }^{2}$ Konkuk University, Seoul, Korea \\ ${ }^{3}$ Shingyeong University, Hwasung, Korea \\ ${ }^{4}$ Inje University Ilsan Paik Hospital Sports Medical Center, Goyang, Korea
}

\begin{abstract}
PURPOSE The purpose of this study was to investigate the effect of 12-week combined aquatic exercise on body composition, muscular function, static balance and visual analogue scale in female elderly with knee osteoarthritis (OA).

METHODS A 66-year old female OA patient participated in this case study. The subject were participated in 12week aquatic exercise based on flexibility, balance, strengthening, aerobic, coordination, muscle endurance. The aquatic exercise performed three times a week, 60 minutes per session for 12 weeks. Pre and post 12 weeks of combined aquatic exercise program participation, body composition, muscular function, static balance, visual analogue scale, were measured using appropriate tools and methods.

RESULTS After the 12-week combined aquatic exercise program, fat free mass increased $0.8 \mathrm{~kg}$ and fat mass decreased $1.1 \mathrm{~kg}$, weight decreased $0.3 \mathrm{~kg}, \mathrm{BMI}$ decreased $0.1 \mathrm{~kg} / \mathrm{m}^{2}$, waist circumference decreased $2.2 \mathrm{~cm}$. Muscular function of isokinetic strength of leg muscle in flexion and extension of knee joint improved and the gap between two muscles lessened. Static balance of center of gravity improved and recovered in normal range. Visual analogue scale of VAS, knee score, function score and WOMAC index improved and reduced the pain.

CONCLUSIONS The 12-week combined aquatic exercise program effected on the body composition, muscular function, static balance and visual analogue scale.
\end{abstract}

Received: October 2, 2017

Accepted: March 30, 2018

Published online: April 30, 2018

Keywords:

Body Composition

Combined Aquatic Exercise

Muscular Function

Static Balance

Visual Analogue Scale
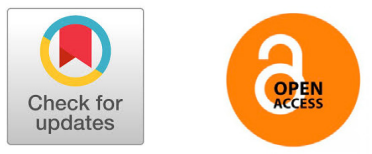

(c) The Asian Society of Kinesiology and the Korean Academy of Kinesiology

서론

인구의 고령화 현상에 따라 만성 퇴행성 질환의 유병률 이 증가하고 있다(Lim. et al., 2014; Lim, \& Kang, 2016). 우리 나라 전체 노인 인구의 $90.9 \%$ 가 만성 질환을 한 가지 이상 앓고 있으며, 가장 유병률이 높은 만성 질환은 퇴행성관

* Correspondence: Ji-Hoon Cho, Shingyeong University Department of Sports \& Leisure Studies, 400-5, Namyangjungang-ro, Namyang-eup, Hwaseong-si, Gyeonggi-do, 18274, Republic of Korea.

**Correspondence: Jung-Wha Moon, Inje University Ilsan Paik Hospital Sports Medical Center, 170, Juhwa-ro, Ilsanseo-gu, Goyang-si, Gyeonggi-do, 10380, Republic of Korea. E-mail:jhchopro@hanmail.net (J.Cho); jhmoon@paik.ac.kr (J. Moon).
절염이다(KOSTAT, 2016). 노령화에 따른 인구학적 현상 을 고려할 때 앞으로 관절염 발생률은 더욱 증가할 것으 로 전망된다(Lim, 2011). 이처럼 관절염의 유병률 및 발생 률의 증가가 예상됨에도 불구하고 아직까지 관절염은 완 치시킬 수 있는 방법이 없기 때문에 (Lee, et al., 2007; Lim, \& Kang, 2016), 환자들은 평생 스스로 질병상태를 조절하면 서 일상생활을 유지하기 위해 자기관리기술을 습득하는 것이 요구된다(Lee, et al., 2007; Lim, \& Kang, 2016).

최근 관절염 환자들의 자기관리방법의 하나로 다양한 운동프로그램이 수행되었는데, 삶의 질, 통증, 유연성, 피 로, 신체구성, 균형, 관절운동범위, 체력과 보행을 포함한 
신체기능의 증진을 향상시킬 수 있는 수중운동(Cochrane

T. et al., 2005; Lee, 2007; Lim et al., 2007; Ko., 2009; Lim, 2011;

Lim. et al., 2014), 근력강화운동(Jo et al., 2006; Kim, 2009;

Han, and Park, 2013), 타이치운동(Chang, 2008; Lee, 2009) 등이 보고되었다.

이 중 수중운동은 몸을 움직이는 동안의 물의 저항과 압력, 물의 와류로 인한 피부순환이 촉진되고 근육이 마 사지되어 이완되고 손바닥을 이용한 물의 저항으로 운동 의 강도를 조절할 수 있고, 부력 때문에 체중의 부담 없 이 운동할 수 있으며 운동과 오락을 함께할 수 있다는 장 점이 있어 지역사회 현장에서 가장 많이 사용되고 있다

(Cochrane T. et al., 2005; Choi, et al., 2007; Kim, et al., 2007). 또한, 관절, 뼈, 힘줄, 인대 및 근육에 적은 부하를 주므로 관절염 환자가 규칙적으로 수중운동을 할 경우 특히 효과 적이다(Lee, 2002; Han, and Park, 2013). 관절 질환으로 인 하여 체중 부하 시 지속적인 통증과 관절염 소견이 악화 되는 환자들도 적지 않기 때문에, 이러한 환자들에게 지 상운동을 강조하는 것이 경우에 따라 오히려 해가 될 수 있다(Lim, \& Kang, 2016). 이러한 관점에서 수중운동이 관 절염 환자의 운동치료에 적절한 방법으로 널리 보급되고 있는 추세이다(Lee, 2002; Lim et al., 2007; Lim, 2011; Lim. et al., 2014).

퇴행성관절염 환자들에 게 수중운동 프로그램을 수행 한 연구들에서, Lim et al.,(2007)은 퇴행성관절염을 동반 한 비만 환자를 위한 수중운동프로그램의 효과를 규명하 였다. 연구결과, 수중운동을 받은 집단(20명)은 운동교육 만을 실시한 대조군(18명)에 비해 통증의 감소 및 기능 호 전을 가져온 것으로 나타났다. 이는 퇴행성관절염을 동 반하여 기능 향상을 위한 운동을 수행하기 어려운 비만 환자에서 수중운동이 효과적인 운동 방법으로 추천될 수 있다고 보고하였다. Lee,(2007)는 퇴행성관절염 여성 환 자 15 명을 대상으로 10 개월 동안 주 1 회 60 분씩 수중 운동 치료를 실시하여 정적 기립 균형, 통증 및 관절운동범위 에 미치는 효과를 규명하였다. 연구결과, 수중 운동치료 는 정적 기립 균형과 통증에는 효과가 있었으나 무릎관 절 운동범위에서는 유의한 차이가 나타나지 않았다고 보 고하였다. Lee, et al.,(2007)은 50세 이상의 관절염 여성 37 명을 대상으로 6 주간 수중운동 프로그램을 주 2회 수행 한 후 통증, 피로, 신체구성, 체력 및 심리적 변수에 미치 는 효과를 규명하였다. 연구결과, 수중운동은 어깨의 유 연성을 증가시켰으며 정신건강에 유용한 효과가 있었다
고 보고하였다. Lim. et al.,(2014)은 뼈관절염 환자로 판정 을 받은 60 세 이상의 노인 여성 11 명과, 동일 연령대의 건 강한 여성 11 명을 대상으로 12 주간의 수중운동을 통하여 운동 전·후에서의 신체구성, 건강체력, 동적·정적 평형성 의변화와 상체와 하체를 대변하는 다양한 근육들의 운동 시 근활성도 및 체중분포도와 관절의 통증 감소의 변화를 살펴보았는데, 다소 차이는 있었지만 전반적으로 변화가 있었다고 보고하였다. Lim,(2011)은 60대 퇴행성 무를관 절염 환자를 대상으로 유산소운동군 8 명, 수중 저항성운 동군 8 명으로 나누어 수중운동을 시켰다. 연구결과, 퇴행 성 무릎관절염 환자에게 수중운동은 임상적, 기능적, 심 리적 측면에서 다양한 효과가 나타났으며, 수중 저항성 운동군이 유산소운동군에 비해 더 많은 변인에서 유의한 영향을 미쳤다고 보고하였다.

이상의 선행 연구 결과에 의하면, 퇴행성관절염 환자 들에 게 수중운동 프로그램의 효과를 규명하는 것은 큰 의 미가 있다고 하겠다. 그러나 현재까지 수중운동 프로그 램이 관절염 환자들의 신체구성, 근기능, 균형감각 및 주 관적 통증의 증진에 미치는 명확한 기전은 분명하지 않으 며, 그 결과 또한 일치하지 않음에 따라 아직까지도 많은 혼란을 초래하고 있는 실정이다. 보다 구체적으로, Lim et al.,(2007)의 연구에서 체질량지수의 감소가 미미한 점, 체 지방의 유의한 변화를 가져오지 못한 점 등을 볼 때 8 주간 의 수중운동 프로그램은 체성분에 대한 운동의 충분한 효 과를 살펴보는데 부족한 기간이라 판단된다. 또한, 비만 을 동반한 관절염환자들을 대상으로 하였으나, 수중운동 프로그램의 내용이 체중 감량을 하기에는 저강도였던 점 이 문제점으로 지적할수 있다. Lee,(2007)의 연구는 주 1회 60 분의 운동 빈도가 부족한 것이 아닌가 판단된다. Lee, et al.,(2007)의 연구에서 선행연구와 달리 통증경감 효과가 나타나지 않았는데, 이는 유의성이 확보되지 않았기 때 문인 것으로 판단된다. 또한, 신체구성 변수에서도 유의 한 감소효과를 나타나지 않았는데, 이는 수중운동의 강도 와 기간이 부족하지 않았나 추정된다. 이 연구에서 실험 군과 통제군 모두 연구기간동안 병원에서 시행되는 관절 염 치료방법과 약물효과를 통제하지 못하였으며, 운동을 선호하는 집단을 우선 실험군에 배정하여 집단 간 연령에 대한 동질성이 확보되지 못하였다. Lim. et al.,(2014)의 연 구는 연구대상자 개개인의 체격과 체력에 맞는 운동기구 를 사용하지 않은 것이 문제점으로 지적된다. Lim,(2011) 의 연구는 두 집단(유산소운동군 vs 수중 저항성운동군) 
만을 비교하였는데, 유산소운동과 저항성운동을 포함한 복합운동군을 설정하여 그 차이를 비교하지 못한 아쉬움 이 남는다.

따라서, 본 사례연구는 위에서 제시한 선행연구의 한 계를 극복하고자수행되었다. 본사례연구의 목적은 퇴행 성 무릎관절염이 있는 노인 여성에게 12 주간의 수중복합 운동이 신체구성, 근기능, 정적평형성 및 주관적 통증에 미치는 영향을 알아보는데 있다.

\section{연구 방법}

\section{연구대상}

본 사례연구의 대상자는 66세 노인 여성으로 2005년 W 병원에서 무릎 퇴행성관절염 질환(우측하지는 관절염 4 기, 좌측하지는 2-3기 진행 중)으로 진단 받고 오랜 기간 고생을 하고 있었다. 특히 우측 무릎의 심한 통증으로 평 소에 낮은 신체활동 정도를 보였고, 현재 비만으로 관절 염 관리를 위해서라도 체중을 감량하라는 의사의 권유를 받았으나 무릎의 심한 통증 때문에 걷기, 자전거와 같은 일반적인 지상운동은 오래 지속하지 못하고 실패하기 일 쑤였다. 불어난 체중과 심한 무를 통증이 낙상에 대한 두 려움으로 이어져 신체활동은 점 점 감소하여 12 년 동안 규 칙적인 운동을 못하게 되는 악순환에 빠져 있었다.

본 대상자는 무릎관절 통증 없이 근력을 향상시키고 기능을 회복시킬 수 있는 운동을 찾던 중 2015년 12월 18 일 I대학병원 정형외과에 내원하였다. 정형외과 전문의 의 진료에서 X-ray 결과와 문진(환자의 기타병력으로 특

\begin{tabular}{|c|c|}
\hline $\begin{array}{ll}\text { Variables } & \text { Subject }\end{array}$ & $\mathrm{Kim}, \mathrm{OO}(\mathrm{F})$ \\
\hline Height $(\mathrm{cm})$ & 162.0 \\
\hline Weight (kg) & 72.0 \\
\hline Age (yrs) & 66.0 \\
\hline Body mass index $\left(\mathrm{kg} / \mathrm{m}^{2}\right)$ & 27.4 \\
\hline
\end{tabular}

\begin{tabular}{|c|c|c|c|}
\hline Test Joint Site & Parameters & Classify & Method \\
\hline Knee Joint & $\begin{array}{l}60 \text { degree/sec } \\
180 \text { degree/sec }\end{array}$ & $F / E$ & Peak Torque \\
\hline F/E: Flexion/Ext & ion & & \\
\hline
\end{tabular}

별한 질환은 없는 것을 확인하였으며, 현재 복용중인 약 은 관절염으로 인한 불편할 때마다 복용하고 있는 진통소 염제가 있으며, 직업은 전업주부였다)을 통해 운동의 안 정성을 확인하고 무릎관절 통증을 최소화 할 수 있는 수 중운동이 권고되었으며, 대상자의 신체적 특성은 <Table $1>$ 과 같다.

본 연구에서 연구대상자가 1 명인 사례연구를 수행한 이유는 무릎관절염 질환의 증상에 따라 수중운동의 빈도 와 강도 등을 달리해야 하고, 개인별 맞춤형 수중복합운 동 프로그램을 수행하여 그 효과를 정확히 규명하기 위 해서다.

\section{측정항목 및 방법}

수중복합운동 프로그램 참여 전과 12 주 후에 I대학병 원 스포츠건강의학센터에서 신체구성, 등속성 근기능, 정적평형성, 주관적 통증 검사를 실시하였다.

\section{신체구성}

신체구성(Body Composition) 검사는 생체전기저항법 (Bioelectrical impedence analysis, BIA)으로 생체전기저항 검사 장비(InBody 720, Biospace)를 이용하여 신장(Heigh), 체중(Weight), 체질량지수(Body Mass Index, BMI), 제지 방 량(Free Fat Mass, FFM)과 체지 방량(Body Fat Mass, BFM), 체지방률(\% body fat)을 측정하였고, 허리둘레(Waist Circumference, $\mathrm{WC}$ )는 줄자를 이용하여 측정하였다.

신체구성은 생체전기저항검사 장비 발판에 올라서서 손잡이를 잡고 팔을 30 도 정도 벌리고 서서 편안한 자세 로 1 회 측정하였다. 검사 상의 측정 오차를 줄이기 위하 여 측정 당일 아침에 공복 상태로 측정 3 시간 전부터 음 식물이나 수분, 카페인, 이뇨제 섭취를 제한하고, 48 시간 전부터 알코올 섭취를 제한하였다. 검사 당일에 편안한 복장으로 갈아입고 소지품을 뺀 후 신체구성 검사를 실 시하였다. 허리둘레는 마지막 갈비뼈와 위앞엉덩뼈가시 (Anterior superior Iliac Spine, ASIS)를 수직으로 이은 선 사 이 $1 / 2$ 지점의 둘레를 줄자로 측정하였다. 측정 시 호흡을 편안히 내쉬게 한 후 2 회 측정하여 평균값을 결과 값으로 채택하였다(ACSM, 2016).

\section{근기능}

무릎관절의 근기능을 평가하기 위하여 무릎관절의 통 증이 없는 범위 내에서 관절운동범위 $(\mathrm{ROM})$ 를 정하고 등 


\begin{tabular}{|lll|}
\hline \multicolumn{2}{|l|}{ Table 3. Static Balance Test } & \\
\hline Static Balance & Parameters & Method \\
\hline Center of Gravity (AS) & API & $\begin{array}{l}\text { 2 times test/ } \\
\text { average value }\end{array}$ \\
\hline *AS: Actual Score & MLI & \\
API: Anterior/Posterior Index, MLI: Medial/Lateral Index \\
\hline
\end{tabular}

속성 근기능 검사 장비(Biodex Medical 3.40, BIODEX)를 이용하여 무릎관절의 굽힘(굴곡) 및 폄(신전)을 60degree/ $\mathrm{sec}$ 와 $180 \mathrm{degree} / \mathrm{sec}$ 의 각속도에서 측정하였다. 등속성 근 기능 검사<Table 2>는 앉은 자세(seated position)로 실시하 였고 각각의 각속도마다 2 회 연습 후 3 회 측정하여 발현 되는 최대 근력(Peak Torque)을 결과 값으로 채택하였다 (David, 1993).

\section{정적평형성}

정적평형성 검사는 기립자세(standing position)에서 정 적인 균형유지 능력을 객관적으로 평가하기 위하여 정적 평형성 검사 장비(Biodex balance $\mathrm{SD}, \mathrm{BIODEX)}$ 를 이용하 여 측정하였다. 정적평형성 검사는 컴퓨터와 연결된 발판 (platform) 위에 올라서서 컴퓨터의 모니터를 보면서 검사 자의 지시대로 이행하는 검사이다. 검사는 체중심(Center of Gravity) 검사를 이용하여 전후지수(anterior/posterior index, API)와 좌우지수(medial/lateral index, MLI)를 측정 하였다. 체중심 검사는 검사 장비 발판에 정해진 위치에 올라서서 체중심의 흔들림 정도를 보는 검사이다.

모든 검사는 각각 2 회 측정하여 평균값을 결과 값으로 채택하였다<Table 3>.

\section{주관적 통증}

주관적 통증 검사는 시각적 상사척도(VAS, Visual Analogue Scale), Knee score, Function score, 통증지수(Western Ontario and McMaster Universities Osteoarthritis, WOMAC index)를 측정하였다. 시각적 상사척도(VAS)와 Knee score, Function score는 문답(interview) 형식으로 측정하였고, 통 증지수(WOMAC index)는 설문지 형식으로 측정하였다.

시각적 상사척도(VAS)는 주관적인 통증을 시각적으 로 표시하여 통증변화를 쉽 게 반영할 수 있는 평가도구이 다. 10점 척도로 ' 0 '은 '통증 없음(no pain)', '5'는 '아픔(hard pain)', '10'은 '최대 아픔(very very pain)'으로 되어 있어 주
관적으로 느끼는 통증을 숫자로 표현하는 척도이다<Figure 1>. 시각적 상사척도는 점수가 높을수록 무릎 통증이 심한 것이고, 점수가 낮을수록 무를 통증이 적은 것이다. Knee score는 무릎의 상태를 평가하는 도구로 통증과 관 절운동범위, 관절의 안정성 점수를 합산하여 100 점 만점 에 총점이 높을수록 무릎의 상태가 좋은 것이다. Function score는 무릎의 기능을 평가하는 도구로 걷기 점수와 계 단 오르내리기 점수를 합산하여 100 점 만점에 총점이 높 을수록 무릎의 상태가 좋은 것이다. 통증지수(WOMAC index)는 관절의 통증, 뺏뻣함, 일상생활에서 신체활동 수 행의 어려움을 평가하는 척도로 통증 5 문항, 경직 2 문항, 일상생활 신체활동 수행 정도 17 문항 총 24 문항의 설문지 형식으로 평가하는 도구로 구성되어 있다. 점수는 4 점 척 도( $0=$ 없음(none), $1=$ 약간(mild), $2=$ 중간(moderate), $3=$ 심 함(severe), $4=$ 매우 심함(extreme))로 통증 20점, 경직 8점, 신체활동 수행 정도 68 점으로 전체 항목 중 평가 점수를 합산하여 96점 만점에 총점이 높을수록 무릎의 통증이나 경직, 신체활동 등의 기능적 움직임이 힘든 것이고, 총점 이 낮을수록 무릎의 움직임이 좋은 것이다(Bellamy N. et al., 1988).

\section{수중복합운동프로그램}

수중복합운동 프로그램은 2015년 12월 18일부터 2016 년 3월 8일까지 서울시 소재 S 스포츠센터 수영장에서 12 주 동안 주 3 회, 일일 60 분을 실시하였다. 대상자의 질환 과 연령을 고려하여 수영장 수온은 섭씨 29-30도, 수심은 $1.2-1.3 \mathrm{M}$ 로 유지하였다.

수중복합운동 프로그램의 구성은 미국관절염재 단(AFAP)의 아쿠아운동프로그램 지침에 따라 $\mathrm{Lim}, \&$ $\mathrm{Kang}$,(2016)의 연구에서 제시된 프로그램을 근거로 무릎 관절 퇴행성관절염과 신체활동이 적은 비만, 낙상의 위험 이 높은 것을 고려하여 근력, 근지구력, 유산소, 균형감각 및 유연성운동이 포함된 '수중복합운동'으로 재구성되었

\begin{tabular}{|c|c|c|c|c|c|c|c|c|c|c|}
\hline 0 & 1 & 2 & 3 & 4 & 5 & 6 & 7 & 8 & 9 & 10 \\
\hline $\begin{array}{c}\text { No } \\
\text { pain }\end{array}$ & \multicolumn{1}{c}{$\begin{array}{c}\text { Som. } \\
\text { pain }\end{array}$} & $\begin{array}{c}\text { Hard } \\
\text { pain }\end{array}$ & $\begin{array}{c}\text { Very } \\
\text { pain }\end{array}$ & & $\begin{array}{c}\text { VV. } \\
\text { pain }\end{array}$ \\
\hline
\end{tabular}

* Som: Somewhat, VV: Very Very

Figure 1. Visual Analogue Scale 


\begin{tabular}{|c|c|c|c|c|c|c|}
\hline \multirow{3}{*}{$\begin{array}{l}\text { Exercies } \\
\text { Section }\end{array}$} & \multirow{3}{*}{ Exercise Type } & \multirow{3}{*}{ Exercise Contents } & \multirow{3}{*}{ Frequency } & \multicolumn{3}{|c|}{ Exercise Level } \\
\hline & & & & level 1 & level 2 & level 3 \\
\hline & & & & $0-4 w k$ & $5-8 w k$ & $9-12 w k$ \\
\hline \multirow{4}{*}{$\begin{array}{l}\text { Warm-up } \\
\text { (10min) }\end{array}$} & \multirow{4}{*}{ Flexibility } & - Knee lift, Leg curl, Ankle reach, Cross country ski & \multirow{4}{*}{1 set } & 0 & 0 & \\
\hline & & - Jumping jack & & 0 & 0 & \\
\hline & & - Limbering exercise warm-up & & & 0 & 0 \\
\hline & & - Joint relaxation (ankle, knee, hip, shoulder, elbow) & & 0 & 0 & 0 \\
\hline \multirow{24}{*}{$\begin{array}{l}\text { Main } \\
\text { exercise } \\
\text { (40min) }\end{array}$} & \multirow{5}{*}{$\begin{array}{l}\text { Strength } \\
\& \\
\text { Muscle endurance }\end{array}$} & - knee up \& press down (gluteus maximus toning) & \multirow{5}{*}{$\begin{array}{l}1 \text { set/ } \\
10-12 \text { rep }\end{array}$} & 0 & 0 & \\
\hline & & - Leg curl \& press down (quadriceps, femoris toning) & & & 0 & 0 \\
\hline & & - Knee kick pull down (hamstrings toning) & & & 0 & 0 \\
\hline & & - Lateral leg raise (hip adductors \& abductors toning) & & & 0 & 0 \\
\hline & & - ABS \& core training & & 0 & 0 & 0 \\
\hline & \multirow{13}{*}{ Balance \& Coordination } & - Body alignment & \multirow{13}{*}{$\begin{array}{l}1 \text { set/ } \\
10-15 \text { rep }\end{array}$} & 0 & 0 & 0 \\
\hline & & - Walking (forward/backward/side) & & 0 & 0 & \\
\hline & & -Forward walking (From outside of the knees to inside of the & & & 0 & 0 \\
\hline & & knees, add the strength of the arm patterns) & & & 0 & 0 \\
\hline & & $\begin{array}{l}\text { - Walk with closed eyes } \\
\text { - Walking forward and backward (start-stop-turn) }\end{array}$ & & & 0 & 0 \\
\hline & & - Walking (tandem stance) & & & 0 & 0 \\
\hline & & - Heel walking & & & 0 & \\
\hline & & - Toe walking & & 0 & 0 & \\
\hline & & - Long stride walking & & 0 & 0 & \\
\hline & & - One leg standing & & & 0 & 0 \\
\hline & & \multirow{3}{*}{$\begin{array}{l}\text { - Floating exercise (static \& dynamic balance training) } \\
\text { - Sit on the noodle and move pelvic tilt from left to right and } \\
\text { from front to back }\end{array}$} & & & 0 & 0 \\
\hline & & & & & 0 & 0 \\
\hline & & & & & 0 & 0 \\
\hline & \multirow{6}{*}{ Cardiopulmonary fitness } & - Knee high jogging & & 0 & & \\
\hline & & - Heel high jogging & & 0 & & \\
\hline & & -Wide jogging & 1 set/ & 0 & 0 & \\
\hline & & - Knee cross jogging & 10-15 rep & & & 0 \\
\hline & & - Kick jogging & & & & 0 \\
\hline & & - Deep water running & & & & 0 \\
\hline \multirow{4}{*}{$\begin{array}{l}\text { Cool-down } \\
\text { (10min) }\end{array}$} & \multirow{4}{*}{ Flexibility } & $\begin{array}{l}\text { - Noodle tools: riding a bicycle } \\
\text { (It decreases heart rates and relaxes joints) }\end{array}$ & & 0 & 0 & \\
\hline & & $\begin{array}{l}\text { - Upper body (pectoralis major, trapezius, latissimus dorsi, } \\
\text { deltoid, biceps brachii, triceps brachii) }\end{array}$ & 1 set & 0 & 0 & 0 \\
\hline & & - Trunk (rectus abdominis, erector spinae) & & 0 & 0 & 0 \\
\hline & & $\begin{array}{l}\text { - Lower body (iliopsoas, gluteus maximus, GCM, quadriceps, } \\
\text { hamstrings, hip add./abd., tibialis anterior) }\end{array}$ & & 0 & 0 & 0 \\
\hline
\end{tabular}

으며, 교육은 국제아쿠아피트니스 자격을 소지한 전문가 중복합운동 전문가는 프로그램을 진행하는 동안 수시로 의 지도하에 수중복합운동을 집중적으로 진행하였다. 수 환자에 게 통증 정도를 시각적 상사척도(VAS) '3' 미만인 


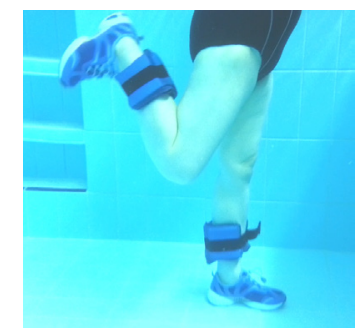

Ankle cuffs(Buoyant equipment)

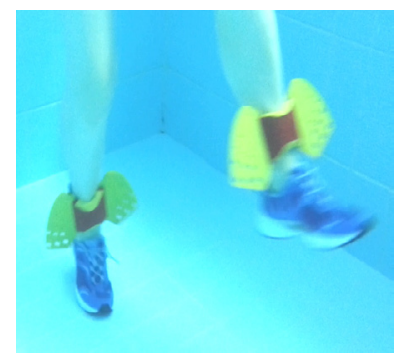

Aqua fin(Drag equipment)

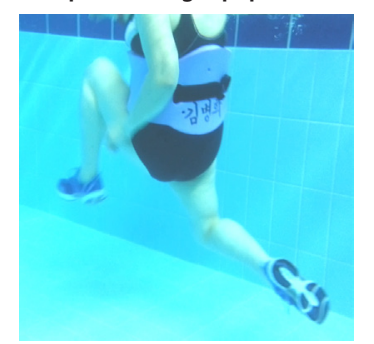

Flotation Belts

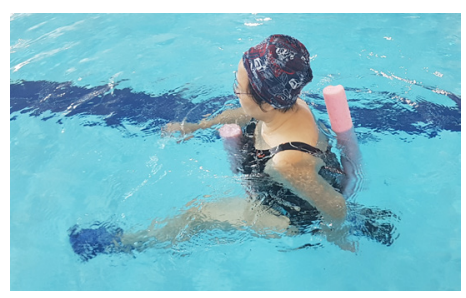

Aqua Noodle

Figure 2. Aquatic Exercise Buoyant Equipment

지를 모니터링 하였고, 운동 강도는 대상자의 특성을 고 려하여 주관적 강도인 RPE(Ratings of Perceived Exertion) 9-15로 강도를 설정하였다.

수중복합운동 프로그램의 단계는 초기, 중기, 후기로 나누어 진행하였다<Table $4>$. 초기단계에는 주관적 강도 인 RPE 9-11로 설정하여 수중에서 기구 없이 물에 적응 하는 훈련을 실시하였고, 중기단계에는 주관적 강도인 RPE 11-13으로 설정하여, 부력저항기구(Ankle cuffs, Aqua Noodle: buoyant equipment)와 부양기구를 사용한 훈련을 실시하였다. 후기단계에는 주관적 강도인 RPE 13-15으로

\begin{tabular}{llll}
\multicolumn{3}{l}{ Table 5. Body Composition } \\
\hline Parameters & pre & post & Improvment \\
\hline Weight (kg) & 72.0 & 71.7 & -0.3 \\
BMl (kg/m²) & 27.4 & 27.3 & -0.1 \\
Fat Free Mass (kg) & 44.3 & 45.1 & +0.8 \\
Fat Mass (kg) & 27.7 & 26.6 & -1.1 \\
\% Body Fat (\%fat) & 38.5 & 37.2 & -1.3 \\
WC (cm) & 92.0 & 89.8 & -2.2 \\
\hline BMl: Body Mass Index, WC: Weist Circumference & \\
\end{tabular}

설정하여, 항력저항기구(Aqua fin: drag equipment)와 무충 격 플로팅 훈련(Flotation belts training)으로 나누어 운동방 법을 구성하였다<Figure 2>. 또한, 각 수중운동의 카테고 리에 근력 및 근지구력을 향상시킬 수 있는 근기능 운동, 균형능력과 협 응력을 향상시킬 수 있는 균형감각운동, 심 폐지구력과 유연성을 향상시키는 운동으로 구성하였다. 운동방법 및 강도는 4 주 간격으로 나누어 0-4주에 초기단 계, 5-8주에 중기단계, 9-12주에 후기단계로 나누어 점증 적으로 증가시켰으며, 운동 시 세트간 휴식시간은 약 30 초-1분 및 운동형태에 따른 휴식시간은 약 2-3분으로 설 정하였다.

\section{결 과}

\section{신체구성 검사 결과}

퇴행성관절염이 있는 노인 여성을 대상으로 12 주간의 수중복합운동 처치 전후의 신체구성 검사 결과는 < Table $5>$ 와 같다.

신체구성 중 제지방량이 $0.8 \mathrm{~kg}$ 증가하였고, 체지방량 은 $1.1 \mathrm{~kg}$ 감소하였으며 체지방률이 $1.3 \%$ 감소하였다. 즉 근육량의 감소 없이 이상적으로 체중과 체질량지수가 감 소하였다. 허리둘레는 $92.0 \mathrm{~cm}$ 에서 $89.8 \mathrm{~cm}$ 로 $2.2 \mathrm{~cm}$ 줄었 다.

\section{근기능 검사 결과}

12 주간의 수중복합운동 처치 전후의 등속성 근기능 검 사 결과는 <Table 6>과 같다.

무릎관절의 근력 평가 기준인 $60 \mathrm{degree} / \mathrm{sec}$ 의 각속도에 서 우측 폄 근력이 $15.4 \%$, 우측 굽힘 근력이 $33.1 \%$ 증가하 였다. 좌우측 근력의 비율은 폄 근력이 $-34.8 \%$ 에서 $-23.1 \%$ 


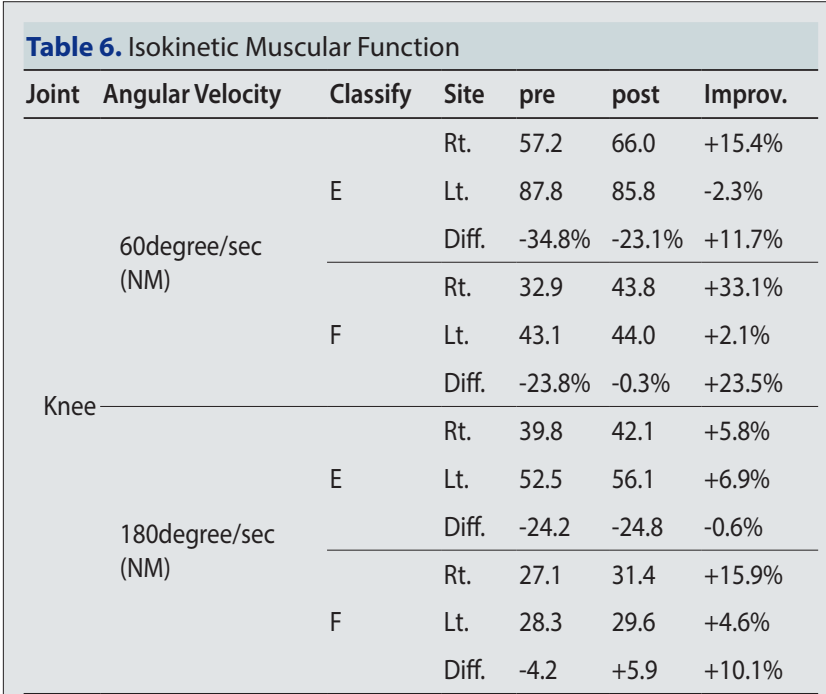

Improv.: Improvement, NM: Newton Meter,

E: Extension F: Flexion

\begin{tabular}{|llllll|}
\hline \multicolumn{2}{l}{ Table 7. Static Balance } \\
\hline Static Balance & Classify & Site & pre & post & Improv. \\
\hline \multirow{2}{*}{ API } & Rt. & 1.5 & 1.1 & $-26.6 \%$ \\
\cline { 2 - 6 } & Lt. & 1.5 & 1.7 & $+13.3 \%$ \\
\cline { 2 - 6 } Center of Gravity (AS) & MLI & Rt. & 1.2 & 1.9 & $+58.3 \%$ \\
\cline { 2 - 6 } & & Lt. & 0.6 & 0.8 & $+33.3 \%$ \\
\cline { 2 - 6 } & \multirow{2}{*}{ Overall } & Rt. & 2.2 & 2.4 & $+9.1 \%$ \\
\cline { 3 - 6 } & Lt. & 1.7 & 2.0 & $+17.6 \%$ \\
\hline API: Anterior/Posterior Index, MLI: Medial/Lateral Index & \\
\hline
\end{tabular}

\begin{tabular}{|c|c|c|c|c|}
\hline Parameters & & pre & post & Improv. \\
\hline Visual Analogue & & 5 & 0 & +5 \\
\hline \multirow{5}{*}{ Knee score } & Pain & 30 & 45 & +15 \\
\hline & ROM & 25 & 25 & 0 \\
\hline & Stability & 25 & 25 & 0 \\
\hline & SD & -7 & 0 & +7 \\
\hline & Total & 73 & 95 & $+30.1 \%$ \\
\hline \multirow{4}{*}{ Function score } & Walking & 10 & 50 & +40 \\
\hline & Stairs & 30 & 50 & +20 \\
\hline & SD & 0 & 0 & 0 \\
\hline & Total & 40 & 100 & $+250.0 \%$ \\
\hline WOMAC index & & 68 & 46 & $23.0 \%$ \\
\hline
\end{tabular}

로 $11.7 \%$ 향상되었고, 굽힘 근력은 $-23.8 \%$ 에서 $-0.3 \%$ 로 $23.5 \%$ 향상되어 굽힘 근력의 좌우측 비율이 정상 범위
(Normal Range)에 속하게 되었다.

무를관절의 근지구력 평가 기준인 $180 \mathrm{degree} / \mathrm{sec}$ 의 각 속도에서 우측 폄 근지구력이 $5.8 \%$, 우측 굽힘 근지구력 이 $15.9 \%$ 증가하였다. 좌측 폄 근지구력은 $6.9 \%$, 좌측 굽힘 근지구력은 $4.6 \%$ 증가하였다. 좌우측 근지구력의 비율은 폄 근지구력이 $-24.8 \%$ 로 사전과 큰 차이가 없었고, 굽힘 근지구력은 $+5.9 \%$ 로 $10.1 \%$ 향상되었다.

\section{정적평형성 검사 결과}

12 주간의 수중복합운동 처치 전후의 정적평형성 검사 결과는 < Table 7>과 같다.

체중심(Center of gravity)은 전후지수는 좌측이 $13.3 \%$ 향상되었고, 좌우지수는 좌측이 $33.3 \%$, 우측이 $58.3 \%$ 로 크게 향상되었다. 특히 좌우지수에서 무릎 통증이 심했 던 우측의 정적평형성이 큰 향상을 보였다.

\section{주관적 통증 검사 결과}

12 주간의 수중복합운동 처치 전후의 주관적 통증 검사 결과는 < Table 8>과 같다.

시각적 상사척도(VAS)는 '5'인 '아픔(hard pain)'에서 ' 0 ' 인 '없음(no pain)'으로 크게 감소하였다.

Knee score는 100점 만점 기준, 73점에서 95점으로 $30.1 \%$ 향상되었고, Function score는 100 점 만점 기준, 40 점 에서 100 점으로 $250.0 \%$ 크게 향상되었다.

통증지수(WOMAC index)는 96점 만점 기준, 68점에서 46점으로 감소하여 $23.0 \%$ 향상되었다.

\section{논의}

\section{신체구성}

인체는 근육, 신경, 뼈, 인대, 힘줄, 피부, 무기질과 지방 으로 구성되어 있으며, 체중은 제지방(Fat Free Mass; FFM) 과 체지방(Body Fat Mass)으로 이루어져 있다(Yoo, 2005). 관절염 환자집단에게 신체조성의 변화는 치료적 목표로 서 중요한 부분이며, 신체 조성은 식습관, 운동습관, 성장 및 발달 등에 의해 건강과 질병 상태를 결정하는 중요한 요소라고 하였다(Evans, 1999). 또한 노화에 따른 신체조 성의 변화 요인 중 제지방량의 감소는 노인들에게서 볼 수 있는 가장 일반적인 특징이며 감소된 제지방은 주로 골격근의 소실로 이루어진다. 그러나 신체활동 및 식습관 등의 변화를 통하여 근육량의 증가와 체지방량의 감소 효 
과가 나타날 수 있으며, 이러한 결과는 전체 체중의 감소 를 유도하여 체중부하에 의한 무릎관절이나 엉덩관절의 하중 부담을 상당부분 감소시키고 통증을 포함한 장애 요 인을 개선 할 수 있다고 하였다.

본 사례연구 결과 수중복합운동으로 신체구성 개선 및 허리둘레가 감소한 것으로 나타났다. 신체구성 중 체지 방량과 체지방율, 체중, 체질량지수가 감소되었고 허리 둘레가 감소되었다. 이와 관련하여 선행연구를 살펴보 면, Kang,(2001)은 수중운동으로 관절에 부담을 덜어주면 서 운동능력은 향상되었고 신체구성이 개선되었다고 보 고하였으며, 12 주간 수중운동에 참여한 뼈관절염 여성은 대조군에 비해 체중, 체질량지수, 체지방률이 유의하게 감소하였다고 보고하였다(Kim, 2009). 65세 이상 여성 노 인에 게 8 주간 수중운동 프로그램을 실시한 후 체지방량, 체지방률, 비만도가 감소하였다는 Ko, et al.,(2009)의 연구 와 수중운동이 체중이 감소하고 근육량이 증가하였다고 보고한 Choi, et al.,(2007)의 연구, 수영운동이 체중, 체지방 량, 체질량지수에 있어 긍정적인 효과를 보고한 Kenney et al.,(2015)의 연구결과는 본 사례연구의 결과를 뒷받침해 주는 결과임을 알 수 있다. 또한, 신체구성의 개선 중 제 지방량, 즉 근육량이 증가하였다. 이는 무를 통증이 심하 고 비만으로 신체활동량이 적어 낙상의 위험이 높은 노 인이라는 점을 감안하여 볼 때, 본 사례연구에서 적용된 수중복합운동이 체지방량과 체지방율, 체질량지수, 체중 이 감소함과 동시에 제지방량, 즉 근육량을 증가시켰다는 것은 큰 이득이라고 생각한다. 그리고 본 사례연구 운동 프로그램의 구성이 일반적인 아쿠아로빅과 같은 수중운 동이 아닌 심폐지구력 강화를 위한 '유산소성운동'과 근 육량의 소실을 막고 제지방량을 증가시키기 위한 '저항성 운동'이 포함된 '수중복합운동'으로 구성된 효과라고 생 각된다.

\section{근기능}

일반적으로 수중운동은 물의 저항을 이겨내며 물속에 서 걷기, 계단 오르기, 중량들기 등의 운동 수행을 가능케 함으로써 근육 및 골격계의 기능이 향상하는 것으로 보고 되고 있다(Dishman, 1987). 본 사례연구 결과 무릎관절의 근력 및 근지구력의 모든 항목에서 근기능이 증가한 것으 로 나타났다. 이러한 결과는 관절염 환자의 수중 운동은 물속에서의 부력 작용으로 인한 체중 부하와 관절에 대한 압력을 감소시켜 지상에서 보다 원활한 움직임을 유발한
것으로, 수압과 물의 점성에 의해 발생하는 저항이 유·무 산소성 운동 수행을 가능하게 하여 심폐지구력, 근력 및 근지구력 향상을 극대화 하였을 것이라 생각한다.

이와 관련하여 선행연구를 살펴보면, Ruoti,(1994)와 Cochrane T. et al.,(2005)은 수중운동이 근골격계에 충격 과 스트레스를 감소시키면서 운동수행능력을 현저히 향 상시키는데 기여한 결과 근력 및 근지구력을 증진시켰다 고 보고하였으며, Jee,(2005)는 뼈관절염 환자에게 유산 소 운동과 등척성 운동을 병행하여 60degree/sec와 180de$\mathrm{gree} / \mathrm{sec}$ 폄근에서 근기능이 향상되었다고 하였고, Choi, et al.,(2007)은 퇴행성관절염 환자를 대상으로 12주간 수 중운동과 무릎관절 운동을 적용한 결과 $60 \mathrm{degree} / \mathrm{sec}$ 와 $180 \mathrm{degree} / \mathrm{sec}$ 에서 우측 굽힘과 폄근, 좌측 폄근에서 유의 한 향상을 보고하였다. 그리고 Han, and Park,(2013)은 볼 (ball)과 밴드(band)를 이용한 8주간의 복합운동이 퇴행성 무릎관절염 여성 노인의 하지근력이 증가하였다고 하였 고, $\operatorname{Lim},(2011)$ 은 퇴행성 무릎관절염 환자를 대상으로 12 주간 수중 유산소운동과 저항성운동 적용에 따른 $60 \mathrm{de}-$ $\mathrm{gree} / \mathrm{sec}$ 에서 좌우측 굽힘근에서 유의한 향상을 보고한 결 과들은 본 사례연구 결과와 일치하였다. 이 사례연구에서 는 특히, 등속성 근기능은 통증이 매우 심했던 우측 무릎 의 등속성 근기능의 현저한 향상을 보였는데, 이 결과로 좌우측 근력의 차이가 줄고, 굴곡근력의 향상으로 동측근 력의 비 $(1: 0.6)$ 차이가 감소하여 무릎관절 통증의 현저한 감소를 보인 것으로 생각된다.

이러한 관점에서 볼 때, 향후 수중운동 이외의 걷기나 자전거, 스포츠댄스 등 다른 운동을 할 수 있는 근력의 바 탕을 마련하는 계기가 될 수 있고 지하철이나 계단을 이 용하는 일상생활에서도 자신감 향상에 긍정적인 기대가 되어 신체활동의 증가로 이어질 것으로 생각된다. 그러 므로 본 사례연구에서 적용된 무릎 관절염 환자를 대상 으로 3 가지 패턴의 수중복합운동프로그램은 유산소성 및 저항성 운동의 기법으로 적용 가능하다는 것을 시사 한다고 생각한다.

\section{정적평형성}

평형이란 기저면 위에 신체중심을 유지하는 능력으로 기능적 활동을 위한 중요한 요인이며, 평형능력의 변화 는 자세 조절에 관여하는 전정감각기관, 시각, 체성 감각 의 세 가지 감각기관과 관련이 있으며, 뼈관절염과 밀접 한 관련이 있다(Bae, et al., 1995). 평형 수행능력의 평가는 
정확한 동작을 수행할 수 있는 자세조절 능력을 결정하는 것으로, 평형성은 크게 정적평형성과 동적평형성으로 나 눌 수 있는데 정적평형성은 자세유지를 할 때 균형을 유지 하는 능력을 말하는 것으로 지지 기저면 내에 중력 중심을 두어 신체가 움직이지 않게 자세를 유지하는 능력이고, 동 적평형성은 신체가 움직일 때 균형을 유지하는 것으로 신 체가 움직이는 동안 중력 중심을 지지 기저면 내에 두어 원하는 자세를 유지하는 능력이다(Bae, et al., 1995).

노인에게서 평형성의 저하는 낙상과 매우 밀접한 관계 가 있으며(Tinetti et al., 1986; Sung, et al., 2004; Kim, et al., 2005; Jo, et al., 2006), 낙상은 노인의 건강을 위협하는 가장 심각한 문제 중 하나이다(Tinetti et al., 1986; KOSTAT, 2016).

본 사례연구 대상은 관절염 통증으로 지상에서 운동 이 불가능했으며 장기간의 운동부족은 균형능력과 신체 활동이 급격히 감소되어 낙상에 대한 두려움이 상당히 있 었다. 그래서 낙상에 대한 두려움으로 동적평형성의 평가 가 불가능하여 상대적으로 안전한 정적평형성을 평가하 였다.

노인의 낙상의 위험을 줄이기 위해서는 평형성 운동이 반드시 포함되어야 하며 노인에 게 정적평형성은 낙상을 예방할 수 있는 자세유지 능력으로 매우 중요한 체력요소 이다. 노년기에 평형성 운동을 규칙적으로 수행하는 노인 은 낙상의 위험을 감소시킬 수 있고(Tinetti et al., 1986; Kim, et al., 2005), 낙상으로 발생하는 골절의 위험도 감소시킬 수 있으며 낙상에 대한 두려움을 경감시킬 수 있다. 이 사 례연구 결과 정적평형성인 체중심의 전후지수, 좌우지수 가 큰 향상을 보였으며, 특히 무를 통증이 심했던 우측 체 중심의 좌우지수가 가장 크게 향상되었다. 이러한 결과는 일상생활에서 앞뒤로 혹은 좌우로 넘어질 수 있는 낙상 위 험이 크게 감소할 것을 시사하며, 향후 낙상에 대한 두려 움도 감소할 것으로 생각된다.

이와 관련하여 선행연구를 살펴보면, Jeong, and $\mathrm{Kim},(2010)$ 은 뼈관절염 환자를 대상으로 자조관리.수중운 동 프로그램 적용 후 평형능력이 향상되었다고 하였으며, Han, and Park,(2013)은 볼과 밴드(band)를 이용한 8주 복 합운동이 퇴행성무릎관절염 여성노인의 보행기능이 증 가하였다고 보고하였고, Seong,(2006)은 퇴행성 무릎관절 염 여성을 대상으로 등속성운동과 밸런스 운동 적용 후 균 형감각이 증가하였다고 보고하였으며, Vellas et al.,(1997) 은 눈 감고 외발서기와 넘어짐의 관련성에 대해서 3 년간 추적 조사를 한 결과 외발서기와 넘어짐과의 관련성이 아
주 높다는 연구 결과와 Fiatarone et al.,(1990)과 Roberts et al.,(1993)의 연구에서 6개월 동안 수중운동을 통한 근육 강 화 훈련을 시킨 결과 평형성이 향상되었고, 노인들의 근력 을 증진시키면 균형 감각이 향상되었다고 보고하여 수중 운동이 균형능력 향상에 유의한 영향을 미친다는 이 사례 연구의 결과를 뒷밭침하는 결과임을 알 수 있다.

\section{주관적 통증}

Fransen(2004)에 의하면 퇴행성관절염은 만성질환이므 로 통증 관리에 초점을 맞추어야 한다고 하였으며, 이러 한 통증은 주관적인 개념으로 개인적이고 경험적이며 신 체적이기도 하나 정신적, 심리적 요인도 포함하는 다양한 특성의 의미를 포함 하고 있다(Sternbach, 1968). 통증으로 인하여 근력약화 및 불안정으로 관절사용이 감소되고, 이 로 인한 스트레스와 일상생활의 기능장애 및 불편감을 초 래할 수 있다(Mindhanm, et al., 1981). 관절염 환자를 대상 으로 수중운동이 통증을 경감시킬 수 있다는 다양한 연구 결과가 제시되고 있다(Lee, 2007; Choi, et al., 2009; Han, and Park, 2013).

본 사례연구 결과 시각적 상사척도(VAS)는 '아픔'에서 '없음'으로 현저한 감소의 결과를 확인하였으며, 이러한 결과는 만성질환이 있는 노인 여성에게 삶의 질의 상당 한 개선 효과가 있다고 할 수 있다. 또한, Knee score는 물 론 Function score 역시 만점으로 향상되었으며, WOMAC index 역시 $23 \%$ 감소되어 무릎의 기능에 대한 환자의 주관 적 통증 평가 지표의 큰 향상을 보였다.

일반적으로 낙상에 대한 두려움을 가진 노인은 낮은 주 관적 건강도, 신체기능의 약함, 신체활동 부족, 적은 사회 활동 등의 특징이 있는데(Howland et al., 1998), 이러한 주 관적 통증 평가 지표의 향상은 관절염 통증으로 신체적, 정신적, 그리고 기능적인 문제점과 낙상에 대한 두려움을 가지고 있던 노인 여성에게 신체적 및 정신적인 자신감과 일상생활의 기능에 있어서 긍정적인 효과를 줄 것이라고 생각된다.

본 사례연구와 관련된 주관적 통증의 선행연구를 살펴 보면, Foley et al.,(2003)은 뼈관절염 환자를 대상으로 6주 간 수중저항운동을 실시한 결과 시각적 상사척도(VAS)가 감소하였으며, WOMAC index가 유의하게 감소되었다고 보고하였으며, Lim,(2011)은 12주간 수중 유산소 및 저항 성 운동을 실시한 결과 시각적 상사척도(VAS)와 WOMAC index가 유의하게 감소하였다고 보고한 연구결과는 본 사 
례연구의 결과를 뒷받침해주는 결과임을 알 수 있다. 이러 한 결과는 관절염을 가지고 있는 노인들에게 안정성을 제 공하고 재미를 고려한 수중복합운동 프로그램의 적용은 체중부하와 관절의 압박이 낮기 때문에 무릎의 통증 완화 뿐만 아니라 신체구성 개선 및 근기능 향상, 정적평형성은 물론 주관적 통증 개선에도 크게 기여하여 삶의 질 부분까 지 개선될 것으로 생각된다.

\section{연구자의 질적인 관점}

운동 시작 2 주차 때 평소와는 다르게 아침에 일어날 때, 뺏뺏한 다리가 부드러워 졌고 무릎의 통증이 감소되기 시 작하였다. 운동 시작 6주차 때 무릎의 통증이 거의 사라졌 다. 운동시작 전에는 통증이 심한 오른쪽 다리를 자연스 럽게 굽히지 못하고 체중지지를 못하여 발을 지면에 끌며 다니는 불안정한 보행이었는데, 운동 시작 8 주차 때 정상 적인 보행의 자세로 향상된 것을 대상자, 지도자, 주위가 족 등의 육안으로도 관찰할 수 있었다. 또한, 운동전에는 지상에서 15 분마다 쉬었다 걸어야 했으나 운동 시작 10 주 차 때 1 시간은 연속으로 걸을 수 있게 되었다. 체중이 증가 하면 다리가 불편하고 다시 감소하면 편해진다고 하였으 므로, 수중복합운동 프로그램에 근력운동 및 평형성운동, 유산소운동을 포함하여 체중관리에도 만전을 기하였다.

국내외 아쿠아 수중지도 경력이 19년차인 연구자가 근 골격계 환자를 대상으로 수많은 수중운동 프로그램을 지 도한 결과, 통증 부위 관절의 근력강화나 가동범위 확대의 프로그램은 일시적인 효과만 있을 뿐이므로, 전신의 균형 (balance)을 맞추는 것에 중점을 두고 훈련시키는 것이 무 엇보다 중요하다는 것을 깨달았다. 인체는 사슬(chain)로 연결되었기 때문에 전신의 균형에 맞춰 개선을 해야 원인 이 해소되며, 부상이 있는 부위별 운동만으로는 다른 부위 의 보상으로 일시적인 통증 감소만 나타날 수 있다. 따라 서 수중운동 프로그램에 균형 향상 운동이 필수적으로 포 함되어야 한다. 지상에서는 통증으로 인해 밸런스 운동을 하기 어려운 데, 수중에서는 물의 부력과 저항을 이용하여 전신의 밸런스를 향상시킬 수 있는 최적의 환경이다.

수중에서는 같은 움직임을 해도 지상에서와는 반대 의 근육작용이 일어난다. 이는 중력의 방향과 부력의 방 향이 정반대이기 때문이다. 따라서 수중운동은 평소 지배 하고 습관화된 근육작용이 아닌 다른 기전의 근육작용이 일어나게 된다. 지상에서의 운동은 주로 닫힌 사슬(closed chain)의 운동이며 심폐운동이 주가 되고, 수중운동은 열
린 사슬(open chain)의 운동이며 밸런스 운동이 주가 된다. 본 사례연구에서 훈련 중기에는 용구의 특성을 살려 한 근육을 단축성(concentric contraction)과 신장성(eccentric contraction) 훈련으로 단련시켰으며, 훈련 말기에는 주동 근(agonist)과 길항근(antagonist)의 근육을 동시에 강한 힘 으로 단축성으로 훈련시켰다. 이는 수중훈련의 장점인데, 본사례 연구에서 이러한 모든 장점들을 모두 적용하였다.

고령화 시 대의 수명 연장에 비해 신체 기능은 관리하지 않으면 따라 갈 수없어 힘든 노년기가 될 수 밖에 없다. 이 를 개선시키기 위해서 퇴행성관절염이 있는 노인 여성은 운동을 습관화하고 자기 관리를 철저히 하는 것이 고령화 사회의 건강유지의 비법이며 최선의 대안이라 생각된다.

\section{결론}

이 사례연구에서는 관절염 노인 여성 환자를 대상으로 12 주간의 수중복합운동이 신체구성, 근기능, 정적평형성 및 주관적 통증에 긍정적인 효과가 있다는 것을 검증하였 다. 향후에는 관절염 노인 환자를 대상으로 수중복합운동 의 추가적인 효과적 검증을 위한 다양한 사례연구와 일반 화를 위하여 보다 많은 대상자들에게 적용한 비교연구가 이루어져 다양한 변인에 대한 추가적인 연구가 필요하다 고 생각된다.

\section{Acknowlegdement}

이 논문은 2014년 정부(교육부)의 재원으로 한국연구재 단의 지원을 받아수행된 연구임(NRF-2014S1A5A2A01013 063).

\section{Conflicts of Interest}

The authors declare no conflict of interest.

\section{References}

ACSM (2016). ACSM's Guidelines for Exercise Testing and Prescription(10th eds.). Philadelphia. Lipponcott Williams and Wilkins. pp. 174-177.

Aquatic Exercise Association (2017). AEA Arthritis Foundation Program. (Co) BOOKK. ISBN: 979-11-272-1161- 
5.

Aquatic Fitness Professional Manual(2010). Human Kinetics. ISBN-13: 978-0-7360-6767-6.

Bae, S. C., Lee, H. S., Yun, H. R., Kim, T. H., Yoo, D. H., \& Kim, S. Y. (2001). Cross-cultural adaptation and validation of Korean Western Ontario and McMaster Universities(WOMAC) and Lequesne osteoarthritis indices for clinical research. Osteoarthritis Cartilage, 9: 746-750.

Bae, S. S., Goo, H. S., Kim, S. S. (1995). Therapeutic Exercise. Seoul: (Co) Daihak Seorim, ISBN: 8980160224, 9788980160228.

Bellamy N, Buchanan W. W., Goldsmith, C. H., Campbell, J., \& Stitt, L. W. (1988). Validation study of WOMAC: a health status instrument for measuring clinically important patient relevant outcomes to antirheumatic drug therapy in patients with osteoarthritis of the hip or knee. The Journal of Rheumatology, 15: 1833-1840.

Chang, K. O. (2008). Effect of Tai Chi Exercise Program on Muscle Strength, Grip Strength, Flexibility, Pain, Depression and Self-efficacy in Patients with Osteoarthritis. Journal of Muscle and Joint Health, 15(2): 130-139.

Choi, H. G., Kim, N. S., Kim, H. S. (2009). Effects of Water Exercise Program on Physical Fitness, Pain and Quality of Life in Patients with Osteoarthritis. JMJH, 16(1): 33-37.

Choi, P. B., Lee, D. T., Jin, J. G. (2007). Effects of aqua-exercises and knee joint-exercises on body composition and bone mineral density levels in elderly with osteoarthritis, Journal of Physical Education of Korea, 46(2):379387.

Crossley, K. M., Bennell, K. L., Cowan, S. M., Green, S. (2004). Analysis of outcome easures for persons with patellofemoral pain: which are reliable and valid? Archives of Physical Medicine and Rehabilitation. 85:815-822.

Cochrane T., Davey R. C., Matthes Edwards S. M. (2005). Randomised controlled trial of the cost-effectiveness of water-based therapy for lower limb osteoarthritis. Health Technol Assess, 9(31):1-131.

David H. P. (1993). Isokinetic Exercise and Assessment. Human Kinetics Publishers.

Dishman, R. K., Parton, R., W \& Smith, J. Weinberq, R., \& Jackson, A. (1987). Using preceived exertion to prescribe and monitor exercise training heart rate. International Journal of Sports Medicine, 8(3):208-213.

Evans W. J. (1999). Exercise training guidelines for elderly. Medicine and Science in Sports and Exercise, 31(1):1217.

Fiatarone, M. A., Marks, E. C., Ryan, N. D., Meredith, C. N., Lipsitz, L. A., \& Evans, W. J. (1990). High-intensity strength training in nonagenarians. effects on skeletal muscle. JAMA, 263(22): 3029-3034.

Foley, A., Halbert, J., Hewitt, T., \& Crotty, M. (2003). Does hydrotherapy improve strength and physical function in patients with osteoarthritis. Annals of the Rheumatic Diseases, 62:1162-1167.

Fransen, M., Nairn, L., Winstanley, J., Lam, P., \& Edmonds, J. (2007). Physical activity for osteoarthritis management: A randomized controlled clinical trial evaluation hydrotherapy or tai chi classes. Arthritis Rheumatology, 57(3):407-414.

Han, S. W. and Park, J. K. (2013). The effects of composition exercise for females elderly from degenerative arthritis on pain, leg muscle strength, ROM and gate function, The Journal of Korean Sports Science, 22(1):1021-1032. Howland, J., Lacman, M. E., Peterson, E. W., Cote J., kasten, L., \& Jette, A. (1998). Covariates of fear of falling and associated activity curtailment.Gerontol., 38:549-555.

Jang, K. O. (2008). Effect of Tai Chi Exercise Program on Muscle Strength, Grip Strength, Flexibility, Pain, Depression and Self-efficacy in Patients with Osteoarthritis, 15(2):130-139.

Jo, S. G., Lee, J. P., Oh, J. G., Kim, H. S. (2006). The Effect of 12 Weeks Strengthening and Stretching Combined Exercise for Balancing Ability in Elderly Women, Women's Sports Journal, 20(1):53-64.

Jee, Y. S. (2005). The Effects on Rehabilitative Exercise on Pain Degree, BOne Mineral Density, and Muscular Functions in Patients with Knee Osteoarthritis. Journal of Korea Sports Medicine, 23(2):152-160.

Jeong, Y. H., Kim, J. I. (2010). Effects of a 9-week Self-help Management - Aquatic Exercise Program on Pain, Flexibility, Balance, Fatigue and Self-efficacy in the Patients with Osteoarthritis. JMJH, 17(1):47-57. 
Kang, D. K. (2001). The effects of aquatic exercise on body composition and serum lipids in obese middle - aged women, Korea Journal of Physical Education, 40(2): 519-527.

Kenney, W. L., Willmore, J. H., \& Costill, D. L. (2015). Physiology Sports and Exercise(6th ed). Chanpaign, IL; Human Kinetics.

Kim, H. S., Hyon, S. G., Kim, N, S., Mok, C. (2005). Comparison of Functional Fitness between Korean and Japanesein the Elderly. Journal of Living Environment, 12(4):352-359.

Kim, H. J., Kim, J. W., Park, K. H. (2007). effects of aquatic exercise program on obese index, growth hormone, igf-1 and vas in obese women with osteoarthritis of the knee, The Journal of Physical Education, 46(4):579-591.

Kim, I. S. (2009). The Effect of an Aquarobic Exercise Program on the Self-Efficacy, Pain, Body Composition, Blood Lipid and Depression in women with Osteoarthritis. Unpublished PhD dissertation, Chonbuk National University. Jeollabukdo, Korea

KOSTAT. (2016). Population and Housing Census. KOSTAT.

Ko., M. J., Lim, E. S., Han, Y. J., Kang, K, S. (2009). Effects of an Aquatic Exercise Program on Physical Fitness, Body Composition and Quality of Life in Elderly Women, Journal of Oriental Medicine, 15(1):9-17.

Lee, B. H. (2007). The Effects of Aqua Exercise Program on Static Balance, Pain and ROM in Female Elders with Osteoarthritis, KSR, 18(5):317-326.

Lee, K. O. (2002). The Effects of Water Exercise on Pain and Depression of Female Elderly Degenerative Arthritis, Korea Archaeology Association, 6(1):105-118.

Lee, S. O., Jang, K. O., Ann, S. H. (2007). Effect of Aquatic Exercise Program on Pain, Fatigue, Body Composition, Physical Fitness and Psychological Variables in Women with Arthritis, Korean Journal of Women Health Nursing, 13(3):165-173

Lee, Y. J. (2009). Effects of the Tai Chi Exercise Program on Physical Functional and Physiological Variables in Patients with Degenerative Arthritis, Journal of muscle and joint health, 16(2):116-124.

Lim, B. O., Kang, S. S. (2016). Review of Aquatic Exercise Pro- gram in Patients with Knee Osteoarthritis. KJSS. 25(3): 1507-1519.

Lim, J. Y., Kim, B. H., CHae, E., Oh, Y. S., Kim, Y. D., Hong, H. J. (2007). The Effectiveness of Aquatic Exercise for Obese Patients with Knee Osteoarthritis: Preliminary Study, Korean Society of Sports Medicine, 25(1):98-105.

Lim, M. Y. (2011). Effects of Aquatic Exercise Types in Clinical, Functional, and Psychological Variables on Patients with Knee Osteoarthritis. Unpublished $\mathrm{PhD}$ dissertation, Dankook University, Chungcheongnamdo, Korea. Lim, S. Y., Kim, S. J., Heo, S. H., Ann, K. J., Lee, J. S. (2014). The effect of regular aquatic exercise on balance capacity, physical fitness and performance level, and muscular activity in elderly women arthritis patients. JKPEAGW, 28(1):37-54.

Mindhanm, R .H., Bagshaw, A., James, S. A., \& Swannell, A. T. (1981). Factor associated with the appearance of pstchiatric symptoms in rheumatoid arthritis. Journal of Psychosomatic Research, 25(5):429-435.

Moon, J. W., Oak, J. S., Park, W. Y. (2004). This research aimed to analyse the effect of 12 week exercise program on muscle fitness, flexibility and balance in the fall down female elderly. Exercise Science. Korean Society of Exercise Physiology, 13(1):77-86.

Roberts, B. L. \& Wykle, M. L. (1993). Falls among institutionalized elderly. Journal of Gerontological Nursing, (May): 13-20.

Ruoti, R. J., Troup, R., \& Berger, R. A. (1994). The effect of nonswimming water exercise on older adults. Journal of Sports Physical Therapy, 19(3):140-144.

Seong, N, J. (2006). The effects of isokinetic and isokinetic plus balance exercise on the change of functional status, pain and postural control in patients with osteoarthritis of the knee, Unpublished master's sthesis, Konyang University, Daejeon, Korea.

Sternbach, R. A. (1968). Pain: Psychophysiologocal Analysis, New York: Academic Press.

Sung, S. C., Lee, M. G., Kim, H. S. (2004). Effects of age, falling experience, and exercise habit on fitness level in the elderly men. Journal of Physical Education in Korea, KSEP, 13(3): 367-380. 
Tinetti, M. E., Williams, T. F., \& et al., Mayewski, R. (1986). Fall risk index for elderly patients based on number of chronic disabilities. American Journal of Medicine, 80(3): 429-434.

Vellas, B. J., Wayne, S. J., Romero, L., Baumgartner, R. N., Rubenstein, L. Z., \& Garry, P. J. (1997). One-Leg balance is an important predictor of injurious falls in older per- son. Journal of the American Geriatrics Society, (45): 735-738.

Yoo, B. K. (2005). The effects of combined exercise at different intensities on the body composition, cardiovascular function, blood lipid and hormone in the obese women. Unpublished PhD dissertation, Hanyang University, Seoul, Korea. 